Swarthmore College

Works

Summer 2013

\title{
He Made The Books And He Died: The Fiftieth Anniversary Of Faulkner's Death
}

Philip M. Weinstein

Swarthmore College, pweinst1@swarthmore.edu

Follow this and additional works at: https://works.swarthmore.edu/fac-english-lit

Part of the English Language and Literature Commons

Let us know how access to these works benefits you

\section{Recommended Citation}

Philip M. Weinstein. (2013). "He Made The Books And He Died: The Fiftieth Anniversary Of Faulkner's Death". Sewanee Review. Volume 121, Issue 3. 432-438. DOI: 10.1353/sew.2013.0078 https://works.swarthmore.edu/fac-english-lit/290

This work is brought to you for free by Swarthmore College Libraries' Works. It has been accepted for inclusion in English Literature Faculty Works by an authorized administrator of Works. For more information, please contact myworks@swarthmore.edu. 


\section{PROJECT MUSE*}

\section{He Made the Books and He Died: The Fiftieth Anniversary}

of Faulkner's Death

Philip Weinstein

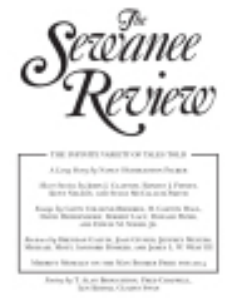

Sewanee Review, Volume 121, Number 3, Summer 2013, pp. $432-438$ (Article)

Published by The Johns Hopkins University Press

DOI: $10.1353 /$ sew.2013.0078

$\Rightarrow$ For additional information about this article

http://muse.jhu.edu/journals/sew/summary/v121/121.3.weinstein.html 
bitter self-pity of Frederic Henry's departing plunge into the rain, Newland "got up slowly and walked back alone to his hotel." If nothing else, Archer has entrusted his son and his son's future to the finest person he has ever known in a world they have shared intimately and yet innocently. For all we know, he might just be smiling contentedly.

\title{
HE MADE THE BOOKS AND HE DIED THE FIFTIETH ANNIVERSARY OF FAULKNER'S DEATH
}

\author{
PHILIP WEINSTEIN
}

"He made the books and he died"-so William Faulkner hoped we might speak of him after death. Only his books mattered-he was certain his life did not. When Malcolm Cowley urged him in 1945 to provide biographical details for Cowley's forthcoming Portable Faulkner, he was more explicit in his resistance: "[the biographical essay] is not for me. It is my ambition to be, as a private individual, abolished and voided from history, leaving it markless, no refuse save the printed books. It is my aim, and every effort bent, that the sum and history of my life, which in the same sentence is my obit and epitaph too, shall be them both: He made the books and he died." Here we are, fifty years after his death: what should we say about the man who wrote those books?

I want to begin by respecting his plea, by not speaking of the flesh-andblood man himself. No one has envisaged more eloquently than he the speechless, post-human, communal life that might follow his entry into the earth:

If there be grief, then let it be but rain,

And this but silver grief for grieving's sake,

If these green woods be dreaming here to wake

Within my heart, if I should rouse again.

But I shall sleep, for where is any death

While in these blue hills slumbrous overhead

I'm rooted like a tree? Though I be dead,

This earth that holds me fast will find me breath.

Faulkner, A Green Bough, poem XLIV 
He sleeps now, rooted and wordless these past fifty years; but we are here today partly because of the extraordinary novels for which, while alive, he labored incessantly to find the words. The question I raise is about the fate of Faulkner's words: do his novels still live in 2013? and, if they do, what in them still burns fiercely, still has the power to astonish his readers?

I raise this question at age seventy-two myself-seven years older than he lived to be, a dozen years younger than Uncle Ike in "Delta Autumn," Uncle Ike who thought he had managed to hold onto just enough wilderness to last until his death. Past eighty, Ike was sure that life harbored no more outrages for him-after having long ago given up the farm, then lost his wife and his son with her-and that the yearly ritual of the wilderness hunt would ceremoniously crown his old age. All readers of "Delta Autumn" know that such peace would not be. Roth's part-black mistress - the "doe"-intrudes upon this idyll of male bonding, shocking the old man with the news that his earlier renunciation of the farm had spoiled Roth rotten and played its part in Roth's abandoning her. Moreover he is forced to learn that the abusive miscegenation launched over a century ago by his grandfather, Old Carothers, has never ceased and is entering now its latest avatar as Roth abandons the doe. "Maybe happens is never once," Quentin muses in Absalom, Absalom!, as outrage perpetuated in the seemingly dead past "abrupts" into the present. All at once, against his will, his defenses shattered, old Ike McCaslin becomes unbearably aware. He has been hurt into life again. Hurt into life, suddenly seeing more than you can bear to see: this, I think, is the essence of Faulkner's fierce hold upon us, a half century after his death.

Let me sketch some reasons why we need this awakening. A few years ago I gave a lecture at the University of North Carolina. As I walked all over the Chapel Hill campus that autumn afternoon, I suddenly became aware of what I had been seeing on my own campus for years now: that none of those beautiful young people ambling from one class to another had anything to say to one another. Each was absorbed in speaking to someone not there; tiny cell phones ruled the scene. These young people had found a perfect way to be not there. In the year 2013 American technology has made it sublimely possible for people to be absent even though physically present. We enjoy an arsenal of gadgets and programs that allows us to traverse space and time as never before. We can connect to anyone we want (on condition that they be elsewhere), and in Tweets and text messages-each with its operative barbarisms - we can enact the ritual of "I'm here/you're there." We need have nothing special to say-just that we're both alive, things are all right. Above all what was happening on that campus-and happens all the time on mine as well-was effortlessness, verging on mindlessness. Finally we have technologies that accommodate and reward the lull of continuous, low-level, ungrammatical acts of communication-a way of being on automatic pilot, half asleep without snoring.

I cannot imagine William Faulkner in such a bland setting. I want to focus 
on why his great work acts as a necessary untamable lion in that sedate garden. My four topics are difficulty, time, race, and the heart.

Faulkner's great novels are difficult to read, but such difficulty is not an embarrassment that his admirers should try to simplify or explain away. The work is fundamentally difficult, in part, because it is engaged with intractable dilemmas of communication and understanding. Who can understand the mind of an idiot? What is going on in the mind of a brilliantly neurotic and suicidal young man on his death day? What might be the mental/ emotional state of a pampered young woman who suddenly finds herself in an alien underworld, where she undergoes abuse repeatedly-from the Frenchman's Bend objects (stove, steps, rat) that abrade her to the stranger who uses a corncob to rape her? How does a young man with "parchmentcolored skin" who may be white but who has been insistently led-ever since his earliest days in a white orphanage-to believe that he is blackhow does he come to grips with his unknowable racial identity? How does an untutored boy from the West Virginia mountains, who has no experience of either race or class, come to deal with a Tidewater world based on race and class differences? What can he do but determine to become the man who most humiliated him-and then suffer the fallout of having become that man?

These situations resist easy communication, and they do so with exponentially more force when we consider-as Faulkner did — the surrounding human dramas they touch and are touched by. How can you tell Benjy's story without bringing in Caddy's, Jason's, Mrs. Compson's? How can you understand Temple without moving through Horace and Popeye? How can you make sense of Joe Christmas without taking into account Bobbie, Joanna, and Lena? How can you grasp what Thomas Sutpen most deeply means without registering the impact of West Virginia, the Tidewater; and Haiti, without factoring in Eulalia Bon, her son, her grandson, and her greatgrandson? All but magnetically Faulkner was drawn to intractable human dilemmas that it took many people and several perspectives to create. If it was easy - if a single change of heart could resolve it - he didn't go there, because the wider consequences would not show. Faulkner wanted incandescent trouble, he wanted the cascading repercussions that would servehauntingly-as a diagnostic X-ray of an entire culture's trouble. It was the culture's trouble he was after, and he knew that it registered personally as an unbearable outrage to individual desire or dignity. No e-mail or conference call or technological gadget could possibly produce an algorithm to solve the dilemmas his characters suffer from. So his work is difficult because lifewhen its troubles rise to an unbearable point-is difficult. These difficulties are lodged too deeply in the texture of life itself to submit to the superficial solutions offered by the array of electronic gadgets we buy to palliate, embroider, and extend our lives.

In his most recent book of essays Jonathan Franzen ponders the anything- 
but-innocent role that these objects play for us. Comparing our relation to such gadgets with our love relations, Franzen writes: "our technology has become extremely adept at creating products that correspond to our fantasy ideal of an erotic relationship, in which the beloved object asks for nothing and gives everything, instantly, and makes us feel all-powerful, and doesn't throw terrible scenes when it's replaced by an even sexier object and is consigned to a drawer." Franzen concludes that "the ultimate goal of technology ... is to replace a natural world that's indifferent to our wishes - a world of hurricanes and hardships and breakable hearts; a world of resistance - with a world so responsive to our wishes as to be, effectively, a mere extension of the self."

Long before Franzen criticized consumer society's capacity to distract us with such palliatives, Freud recognized their siren call. He called these gadgets "prostheses," and in Civilization and Its Discontents he spoke of man as a "prosthetic god," because recent breakthroughs in technology allowed man — even then, in 1929 — to be both here and there, to talk with or telegram to others oceans away. Freud ironically understood the limits of prostheses. In 1929 he was suffering, fatally, from cancer of the throat for which surgeons had implanted a prosthetic jaw. The artificial jaw never ceased to be painful, and he hated what it did to the timbre of his voice. At the time of his eightieth birthday, when approached by admirers to celebrate the event in style, he said no: you celebrate turning eighty, he told them, if your life still feels open to possibility. His did not. He had run up against necessity itself- the Greek term for which, Ananke, he often used in his writings - and there was no going past necessity. Prostheses, even when they start well, eventually collapse; if we are older folks, our knees and hips inform us that we are not gods, and we must submit to the conditions of our humanity. Some things, Faulkner used to tell his own audiences, you have to do for yourself: brush your teeth, but also confront your demons, and also, especially, die your death. These are things no one else-and no array of prosthetic gadgets — can do for you. No less than Freud, Faulkner focused his great work on Ananke-necessity-the consequences that will, though unforeseen at the time, irresistibly follow from your actions. The world as necessity, as indifference, as resistance: so Faulkner envisaged it in his greatest work - the world as boomerang to the utterly human desire to be master of our conditions.

Faulkner's creative breakthrough came from his realizing that the novelistic conventions he had inherited from his nineteenth-century forbears were themselves a form of prosthesis. Progressive plotting, the protagonist's encounter with obstacles that block him at first but that can be negotiated, resolution at the end of the narrative, all of this expressed in clear and grammatical prose - what was this but the prosthetic Victorian novel? A facilitated version of life itself-a genre enabled by being domesticated, artificially made facile_ as though life were a manageable plot, a movement 
through storm into calm. Faulkner knew in his bones that storm is fundamental, not merely a prelude to calm. So he had to refuse the conventional novel's genteel prostheses; he was driven to write about the blood and bones of human necessity. It was the storm he needed to write as it had never been written until then-as sound and fury.

Faulkner's work is difficult as well-and perhaps more deeply sobecause it engages our lives in continuing and overarching time. The Sophoclean truth Faulkner seems to have realized before he was thirty was that, in time, we eventually learn things about ourselves and others that we had no way of understanding when they were happening. This is perhaps the abiding scandal of human life: we don't know enough about what is happening to us and around us when it is happening. We live life forward, as Kierkegaard said over 150 years ago, but we understand it backward. We are all born into a family and a culture that predate us by generations; they didn't wait for our birth before taking on their secrets and complicities. So Joe Christmas will suffer-as Charles Bon and Ike McCaslin will suffer-from parental and grandparental conduct that occurred long before they were born, and whose consequences they cannot free themselves of. Everyone knows, if pushed to know it, that no white or black southerners are free of racial behavior that predates them by at least a century and a half. Faulkner grasped our human creatureliness in just these terms: that what came before us is shaping, and that we begin innocent, unaware of it. Until we realize that, because we exist in a larger time than just our own, there is no innocence to be had. What could be more different from the speed of today's prosthetic gadgets that take you from here to there in an instant? Such gadgets would be worse than useless in that wilderness camp when Roth's white-appearing "doe" walks in on Ike McCaslin and presents him with his necessity: the racial abuse he thought he had sidestepped, the history of miscegenation that emerges as his family's true image and unassuageable guilt.

I move further into the territory of race, the charged terrain of Faulkner's greatest novels. Unlike his white peers he took on this territory. When he looked into the mirror of race, he saw, to use his own phrase, "dark twins." Sometimes darkness dominated (those black others are not me, cannot be me), but sometimes twinship did (those black others are me; how is this scene of injustice bearable?). In his visionary racially focused novels_Light in August and Absalom, Absalom! - he captures the abiding price of southern racism. He took the measure of what it cost whites to have to hate blacks, as well as the cost that blacks-sometimes not knowing they were black - had to pay for this hatred. Deconstructing the biological basis of racism, Faulkner realized that white and black, especially in the South long before the Civil War, were at once officially segregated and intimately, often scandalously, inseparable. To take on these charged materials was courageous, since he knew that he could never get them "right" — no one could. 
But he accomplished something more revealing than getting them right. He showed that, if you were a white southerner immersed in the intractable racial realities of the first half of the twentieth century, even your insight was at the same time a kind of blindness - without ceasing to be insight. You were at once right and wrong.

Finally there is the human heart, and here I speak of both the writer and his work. In his Nobel Prize speech Faulkner declared his crucial concern"the human heart in conflict with itself." As W. B. Yeats knew, out of the quarrel with others we make rhetoric, but out of the quarrel with ourselves we make poetry. Out of his quarrel with himself Faulkner made supreme fictions. As I read the man, he suffered almost daily from knowing who he was-warts and all. He was too intelligent to evade such self-knowledge. He did not manage to change himself-Faulkner's biography is not a success story-but he did manage, throughout his literary career, to invent characters out of his own conflicting inner voices. The speechless Benjy in him jostled with the doomed Quentin in him—and these both jostled with the embittered Jason in him. Let me linger for a moment on Jason, who rarely gets equal time, compared to his compelling brothers. But Jason-like Anse in As I Lay Dying and Joe Brown in Light in August_moves through his world with astonishing vitality. For Faulkner does not judge his own creation: this is his greatest strength as a novelist. Darl and Cash and Addie, Hightower and Byron, Popeye and Horace and Temple, Ike and Lucaseach breathes his or her independent life. They are not only not judged, but they do not have to be right in order not to be judged. This is so, I think, because, neither judging nor forgiving them, Faulkner was able to grant his characters the unstinting fullness of their misdirected lives.

He had stumbled too much in his own troubled life to indict the stumbling of his characters. He had learned non-mastery the hard way: his damaged if not failed marriage; his lies about service in the Great War; his catastrophic offering of his airplane to his youngest brother Dean, who would die in it; his messy love affairs; his desperate need of Hollywood cash; his nearly lifelong enslavement to alcohol. He had gathered a host of demons that he could not make disappear, but he could — and did—make them pay. The dissonance that was Faulkner's life he learned to transmute into the living diversity of his fiction. If fiction's normal task is to give us the storm eventually replaced by the calm of understanding, Faulkner's contribution was to write that storm as it actually assaults us-before it is understood and mapped.

The results are not pleasant to behold. Responding in 1929 to The Sound and the Fury, Evelyn Scott wrote: "Here is beauty sprung from the perfect realization of what a more limiting morality would describe as ugliness. Here is a humanity stripped of most of what was claimed for it by the Victorians, and the spectacle is moving as no sugar-coated drama ever could be." Not prostheses and progress, but necessity and self-reckoning. Old Ike 
McCaslin perceiving that the apparently white woman standing before him subverts the lullabye he had composed of his life: this is the characteristic jolt of Faulkner's great work. It hurts terribly, and the hurt is life.

\title{
REVALUATION
}

\section{JOHN HAWKES AND \\ THE BRIDGE BARELY CURVED}

\author{
ROBERT LACY
}

"Here," Sylvan Karchmer said, handing me a thin paperback. "How about this one?"

We were in the campus bookstore at the University of Oregon in the fall of 1966. With my newly minted MFA from the Iowa Writers' Workshop in hand, I was a rookie assistant professor of English and creative writing, and Karchmer was my senior colleague, helping me select the books I would need for a survey course I was scheduled to teach in the American novel. This one, encased in its distinctive black-and-gray New Directions cover, was John Hawkes's The Lime Twig.

I barely knew who John Hawkes was. My teachers at Iowa, among them Richard Yates, Vance Bourjaily, and R. V. Cassill, were excellent teachers; but their views on what constituted good writing was much more middle of the road than Hawkes. They were of the realist-naturalist school, the Madame Bovary school; but Hawkes, most decidedly, was not. Not wanting to bridle against Sylvan Karchmer's wishes, however-it was he, after all, who had been responsible, as I understood it, for having me hired-I decided to take a flyer on The Lime Twig. And thus was I introduced to one of the oddest, and in many ways sublimest, works in the modern American canon.

Sylvan Karchmer is long dead now, but I still have the copy of The Lime Twig he handed me that day; its cover has come loose from its spine and its pages have yellowed at the edges, but it is otherwise intact. I also still have my notes for the course I would be teaching, some of them written in ballpoint pen on the blank front pages of the novel and some on a half sheet of paper I keep folded inside the book. "Michael's night of lust," one of the lecture notes says, "balanced by Margaret's night of terror." Another says simply, "How Michael redeems himself partially: discuss."

It was the era of the New Criticism: close reading was the order of the day, and The Lime Twig is a close reader's delight. It's the story of a non- 